\title{
SYNERGETIC PRINCIPLES OF MODERNIZATION OF TEACHING NATURAL DISCIPLINES FORMS IN HIGHER MEDICAL EDUCATION
}

\author{
Alexander Chalyi \\ ORCID iD 0000-0002-5755-3875 \\ Doctor of Physical and Mathematical Sciences, Professor, \\ Corresponding Member of the National Academy of \\ Pedagogical Sciences of Ukraine, \\ Academician of the Academy of Sciences of Higher School of Ukraine, \\ Honoured Worker of Science and Technology of Ukraine, \\ Head of the Department of Medical and Biological Physics \\ and Computer Science, \\ Bogomolets National Medical University \\ 13 T. Shevchenko blvd, 01601 Kyiv, Ukraine \\ avchalyi7@gmail.com
}

\section{Oleksii Sysoiev}

ORCID ID 0000-0001-5899-0244

$\mathrm{PhD}$ (Economics),

Head of the Licensing and Accreditation Department,

Kyiv International University

49 Lvivska St, 03179 Kyiv, Ukraine

4998858@gmail.com

\section{Kyrylo Chalyy}

ORCID iD 0000-0001-7077-0324

$\mathrm{PhD}$ (Engineering) (Japan),

Doctor of Physical and Mathematical sciences,

Academician of the Academy of Sciences of Higher School of Ukraine Professor of the Department of Medical and Biological Physics and Computer Science, Bogomolets National Medical University

13 T. Shevchenko blvd, 01601 Kyiv, Ukraine kirchal@univ.kiev.ua

\section{Inna Kryvenko}

ORCID iD 0000-0001-5539-8632

$\mathrm{PhD}$ (Education), Associate Professor of the Department of Medical and Biological Physics and Computer Science, Bogomolets National Medical University 13 T. Shevchenko blvd, 01601 Kyiv, Ukraine innakri18@gmail.com 


\section{Albina Kryshtopa \\ ORCID iD 0000-0003-1034-7342 \\ Senior lecturer of the Department of Medical \\ and Biological Physics and Computer Science, \\ Bogomolets National Medical University \\ 13 T. Shevchenko blvd, 01601 Kyiv, Ukraine \\ alla335578@gmail.com}

\section{Boris Koval}

ORCID iD 0000-0003-3856-6440

Senior lecturer of the Department of Biological Physics,

Medical Equipment and

Computer Science,

National Pirogov Memorial Medical University

56 Pirogova Str., 21018 Vinnytsia, Ukraine

b.koval73@gmail.com

https://doi.org/10.28925/2518-7635.2020.5.3

\section{ABSTRACT}

The educational system is a synergetic system; it is an open, nonlinear, dynamic and complex system. The importance of synergetics for education and science is associated with the possibility of creating a transdisciplinary dialogue, more effective study of interdisciplinary links, using this interdisciplinary direction for a deep understanding of the unity of laws of nature and society, and thus personal development as the ultimate goal of all educational activities. Reforming and modernizing of higher education in Ukraine, increasing the importance of independent work of students in the total amount of classroom and extracurricular training have led to priority interest in the introduction of e-learning content and other components of distance and telematics education, focused on ensuring compliance of national educational standards with international requirements and full participation of Ukraine in the development of European and world educational area. This article outlines the introduction stages of the latest technologies for teaching medical and biological physics with adequate reflection of the specifics of the pedagogical process in higher medical education in Ukraine. The rational combination of the latest technologies and classical methods of teaching natural sciences promotes mutual synergistic strengthening of the effects of their application and minimizes cognitive dissonance and disproportion of information needs and proposals in higher medical education of Ukraine.

The article also tackles the issue of distance learning courses and programs by the world's leading higher education institutions that have resulted in a significant increase in the number of Ukrainian higher education institutions that actively develop and use e-learning Internet resources and other forms of distance learning. 
Key words: modernization, synergetics, implementation of new technologies, teaching, higher medical education

(C) Alexander Chalyi, Alexey Sysoev, Kyrylo Chalyy, Inna Kryvenko, Albina Kryshtopa, Boris Koval, 2020

\section{INTRODUCTION}

The educational system is a synergetic system; it is an open, nonlinear, dynamic and complex system. The importance of synergetics for education and science is associated with the possibility of creating a transdisciplinary dialogue, more effective study of interdisciplinary links, using this interdisciplinary direction for a deep understanding of the unity of laws of nature and society, and thus personal development as the ultimate goal of all educational activities [1-8].

The implementation of strategic objectives of higher education in Ukraine requires the introduction of high-tech information and other science-intensive teaching tools. Current laws adopted by the Verkhovna Rada of Ukraine, orders of the Cabinet of Ministers of Ukraine, in particular, 'Law of 2014 on Higher Education' [9] orders of the Ministry of Education and the Ministry of Health of Ukraine emphasize the need to develop intelligent computer and distance learning technologies (including e-learning content) and create an industry of modern teaching tools. These tasks are also referred to the Priority Areas of Research in Education, Pedagogy and Psychology at the National Academy of Pedagogical Sciences of Ukraine for 2018-2022 [10-13].

\section{MODERNIZATION OF HIGHER EDUCATION}

Reforming and modernizing of higher education in Ukraine, increasing the importance of independent work of students in the total amount of classroom and extracurricular training have led to priority interest in the introduction of e-learning content and other components of distance and telematics education, focused on ensuring compliance of national educational standards with international requirements and full participation of Ukraine in the development of European and world educational area.

The harmonious combination of the latest technologies and classical methods of teaching natural sciences promotes mutual synergistic strengthening of the effects of their application and minimizes cognitive dissonance and disproportion of information needs and proposals in higher medical education in Ukraine.

An important task of our study was to conceptually justify the introduction stages of the latest technologies for teaching medical and biological physics with adequate reflection of the specifics of the pedagogical process in higher medical education in Ukraine. 
There are following stages of the research:

1. Comparative analysis of the features of the latest technologies provision and classical methods of teaching natural sciences in higher medical education in Ukraine.

2. Substantiation of synergetic methods provision in the process of planning, development and effective implementation of modified approaches to teaching natural sciences in higher medical and pharmaceutical education institutions (HMPEIs) of Ukraine.

3. Creation and substantiation of new tools for harmonization and improving the education quality in the pedagogical process modification using a motivational model for the development and implementation of new technologies and classical methods of teaching natural sciences in higher medical education in Ukraine.

The development of telematics and, in particular, distance education in Ukraine began later than in the United States and the European Union and was carried out under conditions of relatively low level of general informatisation of society and insufficient systematization in technological and methodological support of e-learning content. Over the last decade, the basic organizational and legal aspects of the development of the distance learning system in Ukraine have been developed and reflected in the policy documents.

The large-scale introduction of distance learning courses and programs by the world's leading higher education institutions has resulted in a significant increase in the number of Ukrainian higher education institutions that actively develop and use e-learning Internet resources and other forms of distance learning.

In HMPEIs of Ukraine, in particular in Bogomolets National Medical University, is done a lot to improve the quality of information and communication services for staff and students and expand the use of the Internet that creates a technological basis for the development and implementation of e-learning content in all disciplines taught by departments [14]. Providing students with high-quality high-speed Internet access not only in educational buildings, but also in dormitories is constantly being improved, and a network of public wireless Internet connection based on Wi-Fi technologies is being developed.

In order to create conditions for further improvement of the quality of educational-methodological and scientific-pedagogical activities of educators and all categories of persons studying at the HMPEIs of Ukraine, measures are being taken to ensure free Internet access to international bibliographic databases of full-text scientific publications of medical and biological profile, professional publications.

Scientific staff potential of the department of the Department of Medical and Biological Physics and Informatics (MBPhI) in Bogomolets National Medical University (BNMU) is powerful and skilful. This provides an opportunity to conduct research effectively in the main areas of research at BNMU, according to the state strategic priority areas of innovation for 20112021, defined in the 'Law on Priority Areas of Innovation in Ukraine' of Ukraine, 
in particular, on the development and implementation methods of optimizing the teaching and education of students in HMPEIs of Ukraine with extensive use of modern information and communication technologies.

In HMPEIs of Ukraine are implemented organizational measures for the creation of educational portals of universities and the introduction of e-learning content. The strategy for the development of educational portals provides students and teachers with a wide range of information services on the content and learning process. The use of the capacity of portals, the implementation of modern methods of telematics and distance education, successfully complements the traditional full-time and part-time forms of educational work and provides increased quality, convenience and prestige of education. Creating an innovative educational environment using a specialized set of software and hardware allows you to expand the practice of distance learning.

$\mathrm{IBPhI}$ in BNMU conducts active scientific and educational-methodical work and is a reference among single-profile departments in HMPEIs of Ukraine. For 2016-2020, in IBPhI research work (R\&D) has been performed on the following topics:

For 2016-2018 - 'Implementation synergism of new technologies and classical methods of teaching natural sciences in higher medical education of Ukraine;

for 2017-2019 - 'Development and implementation of innovative teaching tools in information disciplines for students of higher medical education institutions';

for 2020-2022 - 'System-synergetic combination of traditional and innovative technologies of teaching natural and information disciplines in the higher medical education of Ukraine'.

These and many other scientific studies create theoretical and methodological foundations for the modernization of higher education in Ukraine. In particular, they provide deepening of interdisciplinary dialogue 'natural disciplines medicine' in HMPEIs of Ukraine.

The proposed modification of approaches to the implementation of educational web content on medical and biological physics and research are provided on the topics:

(a) substantiation of the synergetic system of rational application of the newest technologies and classical methods of teaching natural sciences with adequate consideration of psychophysiological features of the contingent of students;

(b) creation of a motivational model for the introduction of the latest technologies for teaching medical and biological physics, as a tool for improving co-creation relations in the dual complex 'student-teacher' and minimizing cognitive dissonance;

(в) application of assessment criterion and efficiency indicators of the newest technologies introduction in teaching medical and biological physics.

(d) methodology development for teaching physical, mathematical and computer science disciplines in order to deepen the interdisciplinary dialogue 'natural sciences - medicine' in HMPEIs of Ukraine. 


\section{CONCLUSIONS}

The synergetic approach in education and science is based on the similarity of the main features of the processes that occur in systems of different nature, and the models that describe these processes. This allows to transfer the results of one, more accurate educational discipline or science (such as physics) to similar and much more complex objects of another educational field or science (such as medicine).

The rational combination of the latest technologies and classical methods of teaching natural sciences promotes mutual synergistic strengthening of the effects of their application and minimizes cognitive dissonance and disproportion of information needs and proposals in higher medical education of Ukraine.

Synergism of application of the newest technologies and classical methods of teaching natural sciences in higher medical education of Ukraine organically develops traditional (full-time and part-time) forms of educational work and contributes to the harmonization of organizational and methodological principles of participants' interaction in the educational process in the context of building an e-learning environment in HMPEIs of Ukraine.

\section{REFERENCES}

Andruschenko, V. P., Zyazyun, I. A., Flint, V. G., Maksimenko, S. D. (et al.). (2003). Continuous professional education, philosophy, pedagogical paradigm forecast: Monograph. Kremen, V. G. (Ed.). Kyiv: Naukova Dumka (in Ukrainian)

Chalyi, A.V. (2000). Synergetic principles of education and science. (in Ukrainian)

Chalyi, A.V., Tsekhmyster, Ya. V., Stuchinskaya, N.V., Chalyi, K.O., Oliynyk O.I., Paschenko, V.V., Chayka, O.M. (et al.) (2004). Medical and biological physics (2004). (in Ukrainian)

Chalyi, A.V., Tsekhmyster, Ya. V., Stuchinskaya, N.V., Chalyi, K.O., Oliynyk O.I., Paschenko, V.V., Chayka, O.M. (et al.) (2017). Medical and Biological Physis. (in Ukrainian)

Chernavsky, D.S. (2001). Synergetics and information: Dynamic information theory. (in Russian)

Hacken, G. (1980). Synergetics. (in Russian). DOI: 10.1007/978-3-662-10184-1 Lutay, V.S. (2004). The main question of modern philosophy. Synergetic approach. (in Russian)

Mospan, N., Slipchuk, V. (2020). International students in higher education medical institutions in Ukraine: current state of play and prospects. Continuing Professional Education: Theory and Practice, 3, pp. 60-70. DOI: http://dx.doi.org/10.28925/1609-8595.2020.3.7 
Nikolis, G., Prigogine, I. (1979). Self-organization in no equilibrium systems. (in Russian). DOI: https://doi.org/10.1007/978-94-009-6239-2_1

Sysoieva S., Mospan N. (2015). New Law of Higher Education in Ukraine: innovations and risks. Didactica Slovenica, 30(3-4). P. 166-174 http://www. pedagoska-obzorja.si/revija/Vsebine/PDF/DSPO_2015_30_03.pdf URI: http://lib.iitta.gov.ua/id/eprint/711729

Law on Higher Education of Ukraine (2019). Bulletin of the Verkhovna Rada of Ukraine, No243-VIII. 2300 - VIII. (in Ukrainian). URL: https://zakon. rada.gov.ua/laws/show/1556-19.

Law on Education of Ukraine (2019). Bulletin of the Verkhovna Rada of Ukraine, No2657-VIII. 2661 - VIII. (in Ukrainian). URL: https://zakon. rada.gov.ua/laws/show/2145-19.

Law on Amendments to the Law of Ukraine on the National Informatization Program (2018). Bulletin of the Verkhovna Rada of Ukraine, N 27-28, art. 181. (in Ukrainian). URL:http://search.ligazakon.ua/1_doc2.nsf/link1/Z980074.html

On approval of the Concept of development of natural and mathematical education (STEM-education). Order of the Cabinet of Ministers of Ukraine, № 960-p. 05.08.2020. (in Ukrainian). URL: https://zakon.rada.gov.ua/laws/ show/960-2020--\%D1\%80\#Text Phone

\section{СИНЕРГЕТИЧНІ ЗАСАДИ МОДЕРНІЗАЦІЇ ФОРМ НАВЧАННЯ ПРИРОДНИЧИХ ДИСЦИПЛІН У ВИЩІЙ МЕДИЧНІЙ ОСВІТІ}

Чалий Олександр, доктор фізико-математичних наук, професор, член-кореспондент НАПН України, Академік АН ВШ України, заслужений діяч науки і техніки України, завідувач кафедри медичної і біологічної фізики та інформатики, Національний медичний університет ім. О.О. Богомольця, бульвар Тараса Шевченка, 13, 01601 Київ, Україна, avchalyi7@gmail.com

Сисоєв Олексій, кандидат економічних наук, доцент, керівник департаменту ліцензування та акредитації, Київський міжнародний університет, вул. Львівська, 49, 03179 Київ, Україна, 4998858@gmail.com

Чалий Кирило, кандидат технічних наук, доктор фізико-математичних наук, Академік АН ВШ України, професор кафедри медичної і біологічної фізики та інформатики, Національний медичний університет ім. О.О. Богомольця, бульвар Тараса Шевченка, 13, 01601 Київ, Україна, kirchal@univ.kiev.ua

Кривенко Інна, кандидат педагогічних наук, доцент кафедри медичної i біологічної фізики та інформатики, Національний медичний університет ім. О.О. Богомольця, бульвар Тараса Шевченка, 13, 01601 Київ, Україна, innakri18@gmail.com 
Криштопа Альбіна, старший викладач кафедри медичної і біологічної фізики та інформатики, Національний медичний університет ім. О.О. Богомольця, бульвар Тараса Шевченка, 13, 01601 Київ, Україна, alla335578@ gmail.com

Коваль Борис, старший викладач кафедри біологічної фізики, медичної апаратури та інформатики, Вінницький національний медичний університет ім. М.I. Пирогова, вулиця Пирогова, 56, 21018 Вінниця, Україна, b.koval73@gmail.com

Освітня система - ие синергетична система (відкрита, нелінійна, неврівноважена, складна). Синергетичний підхід до освіти та науки відіграє важливу роль, оскільки створюється міждисииплінарний діалог та глибше вивчаються міждисииплінарні зв'язки. Основна місія освітньої діяльності - розвиток особистості, а використання міждисииплінарного напрямку дозволить краще розуміти глобальну систему «суспільство - природа». Ребормування та модернізація вищої освіти в Украӥні, підвищення значення самостійної роботи студентів у загальному обсязі аудиторної та позааудиторнії підготовки призвели до впровадження електронного навчального змісту та інших компонентів дистанційної та телематичної освіти, що зосередженні на забезпечення відповідності національних освітніх стандартів міжнародним вимогам та повної участі Украӥни у розвитку європейського та світового освітнього простору. У иъій статті викладено етапи впровадження новітніх технологій викладання медичної та біологічної бізики та відображено особливості педагогічного процесу у вищій медичній освіті України. Визначено, щзо раціональне поєднання новітніх технологій та класичних методів викладання природничих наук сприяє взаємному синергетичному покращенню викладання та мінімізує когнітивний дисонанс, диспропориію інформаційних потреб та пропозицій у вищій медичній освіті України.

У статті також розглядається питання дистанційних курсів та програм провідних вищих навчальних закладів світу, щзо призвело до значного збільшення кількості украйнських вищих навчальних закладів, які активно розробляють та використовують Інтернет-ресурси електронного навчання та інші форми дистаниійного навчання.

Ключові слова: модернізація, синергетика, впровадження новітніх технологій, навчання, вища медична освіта 